uniform and the same as that of the present, this thickness of rock would have required a period of $I, 526,750,000$ years for its accumulation. Dr. Haughton is not a uniformitarian, consequently he divided this number by 10. Dr. Wallace next made what must be considered a great step in advance, by pointing out that the sediment which is carried into the sea is not deposited uniformly over the whole sea-floor, but, as the Challenger dredgings clearly showed, along a comparatively narrow marginal tract. Instead, therefore, of multiplying $\frac{\pi}{3090}$ (the yearly rate of denudation) by $\frac{5 \pi}{145}$, he divided it by $\frac{1}{19}$ (the proportion of the area of maximum deposition to the area of denudation), and thus obtained 28 millions as the number of years required for the accumulation of 177,000 feet of rock.

A further correction was next made by Mr. C. Davison, who showed that the fraction $\frac{1}{30}$ is obtained by an error in arithmetic, and that the true value is $\overline{2}$ to 0 . Introducing this fraction into Mr. Wallace's calculation, we obtain in round numbers 22 millions of years, a close approximation to the result, deduced from physical considerations, by Mr. Clarence King.

Of late years considerable additions have been made to our knowledge of the thickness of the systems of stratified rock, and I present the following table as representing the maximum thickness of all known formations down to the base of the Cambrian, a definite horizon marked, as is well known by the occurrence of fossil remains of most of the great subdivisions of the Invertebrata :-

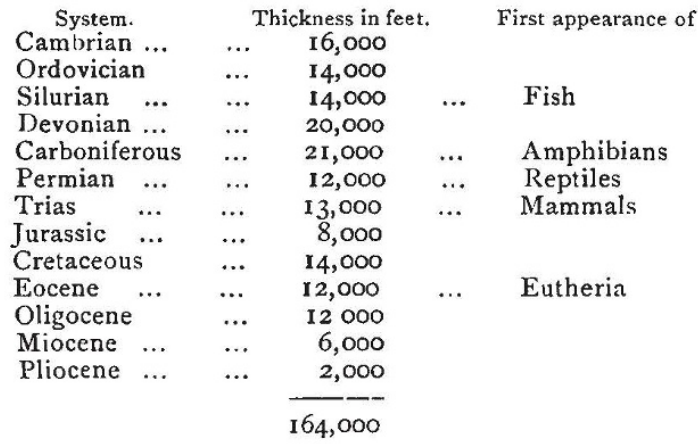

The total thickness is 164,000 feet, lying in a fairly continuous series, and calculating by Mr. Wallace's method, this leads to the conclusion that, in round numbers, 2 I millions of years have elapsed since the beginning of Cambrian times. The truth of Mr. Wallace's argument depends on the assumption that an area of maximum deposition retains a constant position during the existence of a geological system. This is no doubt approximately the case, but so far as it is not, the deviation from stability will render Mr. Wallace's estimate deficient. On the other hand, as Mr. Wallace himself recognised, the area of maximum deposition does not extend uniformly round the coast line, but is concentrated, if one may so speak, near the moutbs of rivers: the effect of taking this into account will far more than compensate for any shifting of the area. It is unnecessary to do more than point out that deposits, where they attain their maximum thickness, are of a more or less deltaic nature, and were probably deposited near the mouth of large rivers, in seas more or less land-locked. From investigations in which I am now engaged, I am led to conclude that where systems attain their maximum thickness, accumulation may have proceeded at the rate of one foot in a century, or even more rapidly.

The question largely depends on the relative size of areas of denudation and deposition: an objector to my estimate may urge that accumulation at this rate involves the existence of areas of denudation of much larger dimensions than the map will find room for. It is worth while to inquire into this, and a single example will suffice. Let us consider the coal measures of the British Isles. Suppose they cover, to the depth of half a mile, a circular area 300 miles in radius, having its centre somewhere over Anglesey, their volume will thus be 141,372 cubic miles; add to this 15,876 cubic miles for the deposits of greater thickness occurring over the North of England, and South Wales and Somersetshire. This gives a total thickness of 157,248 cubic miles. But since the maximum thickness is 12,000 feet, these will have accumulated, according to our assumption of $\mathbf{I}$ foot in a century, in I,200,000 years. The coexistent area of denudation affords $\frac{1}{2400}$ of a foot of sediment per annum, or 00000008 cubic mile per square mile yearly. In $\mathrm{I}, 200,000$ years this will amount to nearly $\frac{1}{10}$ cubic mile per square mile ; and thus the I 57,248 cubic miles of sediment in the coal measures will have required a land surface $1,572,480$ square miles in area for their supply. This will be represented by a circular area with a radius of 707 miles, and that an area of land several times these dimensions may have existed north and west of the British Isles during carboniferous times, is an assertion which most geologists will be prepared to defend.

So far as I can at present see, the lapse of time since the beginning of the Cambrian system is probably less than seventeen millions of years, even when computed on an assumption of uniformity, which to me seems contradicted by the most salient facts of geology. Whatever additional time the calculations made on physical data can afford us, may go to the account of PreCambrian deposits, of which at present we know too little to serve for an independent estimate.

No one can regard without satisfaction the introduction into Lord Kelvin's argument of well-ascertained data as regards the melting points and other properties of rocks. Dr. Joly finds the melting point of basalt to be even lower than that of diabase, viz. $815^{\circ} \mathrm{C}$., a result in accordance with that found by other investigators. These facts, though of great assistance in supporting the short chronologists of the earth's age, may prove embarrassing when the question of the physical state of the interior of the earth is ready for reconsideration. Dr. Joly finds the value of $d t / d p$ for basalt to be 0.006 , and for diabase, according to Carl Barus, it is $0.02 \mathrm{I}$ at $1200^{\circ} \mathrm{C}$.; in either case the temperature gradient gains on the melting point gradient rapidly enough to show that, at no great distance beneath the surface of the earth, the interior, if it consist of such rocks as these, is in a state of liquidity. Geologists in general would probably be glad to purchase an internal liquid shell at a cost of several millions of years. Would not, however, the admission of the existence of liquid shells in the interior of the earth, deprive the mathematical argument, as at present formulated, of all validity?

W. J. SOLLAS.

\section{THE ANNIVERSARY OF THE CHEMICAL SOCIETY}

THE anniversary meeting of the Chemical Society was held at the Society's rooms, on Wednesday March 27, when the following officers and Council were elected :-

President, Dr. A. G. Vernon Harcourt, F.R.S. VicePresidents (who have filled the office of President), Sir F. A Abel, K.C. B., F.R.S., Dr. H. E. Armstrong, F.R.S., Dr. A. Crum Brown, F.R.S., W. Crookes, F.R.S., Dr. E. Frankland, F.R.S., Sir J. H. Gilbert, F. R.S., Dr. J. H. Gladstone, F.R.S. Dr. H. Müller, F.R.S., W. Odling, F.R.S., Dr. W. H. Perkin, F.R.S., Lord Playfair, K.C.B., F.R.S., Sir H. E. Roscoe, F.R.S., Dr. W. J. Russell, F.R.S., and Dr. A. W. Williamson, F.R.S. Vice-Presidents Dr. E. Alkinson, Horace T. Brown, F.R.S., Prof. F. R. Japp, F.R.S., Ludwig No. 1327 , voL. $5 \mathrm{I}]$ 
Mond, F.R.S., C. O'Sullivan, F.R.S., and Prof.W. C. RobertsAusten, C.B., F.R.S. Secretaries, J. Millar Thomson, and Wyndham Dunstan, F.R.S. Foreign Secretary, Prof. Raphael Meldola, F.R.S. Treasurer, Dr. 'T. E. Thorpe, F.R.S. Council, Dr. P. Phillips Bedson, Bennett Hooper Brough, Prof. Harold Dixon, F. R.S., Dr. Bernard Dyer, R. J. Friswell, Otto Hehner, Dr. F. Stanley Kipping, Herbert McLeod, F. R.S., W. A. Shenstone. Dr. Thomas Stevenson, Dr. W. P. Wynne, and Prof. Sydney Young, F.R.S.

Prof. Armstrong, F.R.S., the retiring President, delivered his address, in which he gave an account of the work of the Society during the past year. The Faraday Medal was presented to Lord Rayleigh for the distinguished services he has rendered to chemical science through the discovery of argon. Lord Rayleigh responded in a few words, sharing the honour bestowed on him with Prof. Ramsay. The President then called on Prof. Ramsay, who laid before the Society an account of the discovery of Helium in Clèveite, and on $\mathrm{Mr}$. Crookes, who described it spectroscopically. (These two communications will be found in another column.) In the evening the Fellows and their guests dined together at the Hôtel Métropole. Among those present were:-

Dr. H. E. Armstrong, the Right Hon. Jas. Bryce, M.P., President of the Board of Trade ; the Right Hon. A. J. Balfour, M.P., Sir Henry Roscoe, M.P., Mr. A. Vernon Harcourt, Lord Rayleigh, Sir Walter Prideaux, Clerk of the Goldsmiths' Company ; Dr. W. J. Russell, Mr. T. F. Blackwell, Master of the Salters' Company ; Prof. Odling, Sir Owen Roberts, Mr. Carteighe, Mr. Lavers Smith, Dr. W. H. Perkin, Prof. Thorpe, Dr. J. H. Gladstone, Mr. W. Crookes, Dr. Stevenson, Mr. C. E. Groves, Prof. McLeod, Prof. Percy Frankland, Prof. Rücker, Prof. Dunstan, Dr. Atkinson, Prof. Ramsay, Prof. Emerson Reynolds, Prof. Dewar, Sir H. Gilbert, Prof. Smithells, Prof. Tilden, Dr. Wynne, Mr. Alex. Siemeas, Prof. Thomson, Mr. Thiselton-Dyer, Dr. Hugo Müller, Mr. Norman Lockyer, Sir P. Magnus, Prof. Meldola, Dr. W. H. Symons.

A full report of the speeches made at the dinner appeared in the Times of the following day, and we are indebted to it for the following extracts :-

In proposing the toast of the Houses of Parliament, the President, Dr. H. E. A rmstrong, remarked with reference to argon, that the discovery which Lord Rayleigh and Prof. Ram. say had made was not a chance discovery, but was the outcome of twelve years of hard work on the part of Lord Rayleigh in pursuit of the fourth decimal. The interest in the newlydiscovered argon would undoubtedly be an abiding one, and it was believed that its development would be one of the most extraordinary discoveries that had been made in our time. He also referred to the discovery of Helium by Mr. Norman Lockyer, and its recent identification by Prof. Ramsay and Mr. Crookes.

Mr. Bryce, in responding to the toast, said : Physical science, and particularly chemical science, very frequently came in contact with the work of the administrators of the Government, and hardly a day passed by when they were not connected in some way with electricity or chemistry. He had been greatly impressed by the progress made in the quantity of science teaching, which had in some places almost ousted the literary side of teaching. In spite of that large quantity of science teaching, however, the Universities had not yet provided adequate means for the preparation of science teaching; and although there were a great many men teaching scientific knowledge and teaching it well, enough had not been done to give them a systematic training and to make them not only scientific men, but skilful, finished, and experienced teachers of science as a special branch of instruction. A good deal remained to be done in that way.

Mr. Balfour made the speech of the evening in proposing "Prosperity to the Chemical Society." In the course of his remarks, he said : In the last speech to which we listened with so much pleasure, the President of the Board of Trade reminded us that his department-one of the most important departments in the Government-was brought face to face and in the closest relation to science almost every day in connection with one or other of the great practical questions with which it has to deal. Undoubtedly that is so, but I think he will probably agree with me when I say that we politicians-he and I who are engaged in the work of every-day political conflict-cannot boast that we or those whom we represent are in the position of using science as the handmaid of great national purposes, or that we have the power to turn it and direct its great forces whither we will. For my own part, though the last thing I wish to do is to sug. gest that the work of practical politicians is other than a work which takes the highest qualities of a man, still I have to admit, on looking back on the history of civilisation, that if we want to isolate the causes which, more than any other, conduce to the movements of great civilised societies, you must not look to the politicians of the hour on whom, it may be, all eyes are fixed; you must look to those who, often unknown by the multitude, whose work, it may be, is never properly realised by the men of their country till after they are dead-you must look on them and on their labours to find the great sources of social movements. It is to those who, very often with no special practical object in view, casting their eyes upon no other object than the abstract pure truth which it is their desire to elucidate, penetrate further and further into the secrets of nature and provide the practical man with the material upon which he works-these are the men to whom, if you analyse the social forces to their ultimate units, we owe most, and to produce such men, and to honour such men, and to educate such men, does the Society, whose health I am now proposing, devote its best energies. I do not think, so far as I am acquainted with scientific history, that Englishmen need fear that they have been behind the rest of the world in evolving those root ideas which are the sources of great discoveries, which are themselves great discoveries, and which are, too, the sources and roots of other great discoveries. It may be, however, that though, as a nation, we have been as productive as other nations-I put it modestly -in the men of genius who have made these fundamental discoveries, we have not, as a nation-and I do not think we have-sufficiently realised how great a bearing theory in these modern days must necessarily have upon practice if we are to keep pace with the rest of the world. We have produced great theorists-none greater. We have produced men of great practical genius-none greater. I am not sure, however, that at this moment we are not behind one at least of the great nations of the continent, perhaps more than one, in the art of combining theory and practice-in the art of so welding together in a great organic and self-supporting whole the man of genius, who at one end of the scale discovers a new law of nature, and the man of practice, on the other hand, whose business it is to turn these discoveries to account. I do not venture upon a subject upon which, after all, I am not wholly competent, and I will not develop this subject at greater length; but I should like to do what I can to dispel the prejudice which certainly exists at this moment in certain influential quarters against technical education properly understood. Technical education properly understood, suffers greatly under technical education improperly understood, and there is so much nonsense talked upon this subject, there is so much money uselessly spent, there are so many things taught to persons who do not want to learn them, and which, if they did want to learn them, they could by no possibility turn to practical account, that it is no matter of astonishment that some persons are disposed to say that "technical education is only the last bit of political humbug, the last new scheme for turning out a brand new society; it is worthless in itself, and not only is it worthless, but it is exceedingly expensive." While I think that those who object to technical education have their justification, it yet remains true that if you include, as you ought to include, within the term technical education, the really scientific instruction which would turn scientific discoveries to practical account-if that is what you mean, or what you ought to mean, by technical instruction, then there is nothing of which England has at this moment any greater need, and there is nothing which, if she, in her folly, determines to neglect it, will more conduce to the success of her rivals in the markets of the world, and to her inevitable abdication of the position of commercial supremacy which she has hitherto held. I do not deny that manufactures and commerce have received an immense amount of gain from theoretical investigations, and, as everybody will admit who has even the most cursory acquaintance with, let us say, the history of discoveries in electricity and magnetising power, science has been the means of great gain through industrial development. While both these things are true, I am the last person to deny that it is a poor end, a poor object for a man of science to look forward to of merely making 
money for himself and other people. After all, while the effect of science on the world is almost incalculable, that effect can only be gained in the future, as it has oniy been gained in the past, by men of science pursuing knowledge for the sake of knowledge and for the sake of knowledge alone; and if I thought that by anything that had dropped from me to-night I had given ground for the idea that I looked on science from what is commonly called a strictly utilitarian point, that I measured its triumphs by the number of successful companies $w$ hich it had succeeded in starting, or by the amount of dividends which it gave to capitalists, or even by the amount of additional comfort which it gave to the masses of population, I should greatly understate my thought; but I know that this great Society, while it has in view these useful objects, still puts first of all the pursuit of truth as its object and as the cause to which every man of science pays his devotion. Truth, not profit, must necessarily be the motto of every body of scientific men who desire to be remembered by posterity for their discoveries. These things can be done only from a disinterested motive, and it is because $\mathrm{I}$ believe that societies like the great Society I am addressing do more than any other organisation to attain that great object, because I think they bring together men engaged in congenial pursuits, because the stimulus of minds brought close to other minds with honourable motives, and the honourable rivalry of men engaged in the same great task, must lead to an enormous expansion of our knowledge of the secrets of nature, that I, as an outsider, not belonging to your body, but in the name of the public for which I venture to speak, wish you all success and all prosperity.

The President briefly responded to the toast.

Mr. Vernon Harcourt proposed "Learned Societies," coupled with the name of Lord Rayleigh, who briefly responded.

Sir Henry Roscoe proposed "The Visitors," and Sir Owen Roberts and Prof. Riticker responded.

Dr. W. J. Russell proposed "The President," who concluded with the roast of "The Secretaries," coupled with the name of Prof. Thomson.

\section{SIR HENR Y CRES WICKE RA WLINSON, BART.}

HENRY CRESWICKE RAWLINSON was de1 scended from the family of Rawlinsons who, in the last century, settled down at Chadlington, in the county of Oxford; he was born April I I, I810, and in I862 he married Louisa Caroline Harcourt, daughter of Henry Seymour, of Knoyle, Wilts, and he died on March 5 last. At the early age of seventeen he went out as cadet to India, and in a very short time made himself an excellent Persian scholar; in 1833 he was sent to Persia, his fine command of the language of that country, no doubt, influencing his selection by "John Company." For six years he served diligently, and filled many military posts in the great cities of Persia, and he succeeded in infusing something nearly akin to order in the forces of the "King of Kings." In I 839 the relations between England and Persia became "strained," and Rawlinson left the country for Afghanistan; in 1840 he was appointed Political Agent of the Indian Government in Kandahar, a post which he held until I 842 . During these years he wielded the sword as often as the pen, and his courage and personal bravery in the field made him a terrible opponent of the wily Afghan. In 1844 he was sent to Bagdad as H.B.M.'s Consul for Turkish Arabia, and in I85I he was made Consul-General, the importance of Bagdad being, thanks to Rawlinson's labours, fully recognised. In 1855 he was made Crown Director of the East India Company, and in 1856 he was promoted to the dignity of K.C.B.; two years later he was elected Member of the India Council, and in 1859 he was sent to Teheran as Minister Plenipotentiary. He represented in Parliament for a short time $(1865-1868)$ the borough of Frome, but a Member's life offered no attractions to him.

The above brief statement of facts will indicate sufficiently the abilities of Rawlinson, who was a man equally able as a statesman, diplomat, and soldier; but there is yet another side of him of which nothing has been said, and it is that of the scholar. Before Rawlinson had been five years in India, he had read the greater part of the literature of Persia, and he was even at that time (I832) a skilled and fluent talker in Persian; long passages from the finest poets he had learned by heart, and his conversations were so full of extracts from them, that a native once described his talk as "a garden of pearls in metre." From modern Persian to the ancient language is, relatively, but a step, and when Rawlinson found himself in Persia in 1833 , he turned his mind to the study of the remains of the kings who had cut their records in the rocks in the cuneiform characters. So far back as I 835, he copied the tablets at Hamadän, and without the help of books, or even any knowledge of the alphabet worked out by Grotefend in 1802, by making the same guesses as Grotefend, he identified correctly the names of Hystaspes, Darius, and Xerxes. In 1836 he collated the first paragraphs of the great Behistun inscription with the tablets at Elwend, and identified the old Persian forms of the names Arsames, Ariaramnes, Teispes, Achaemenes, and Persia; by this time he had made an alphabet of eighteen characters. Early in 1837 he had copied all the other paragraphs of the Behistun inscription, and in the winter of that year he sent to the Royal Asiatic Society his translation of the two first paragraphs which recorded the genealogy and titles of Darius Hys taspes. Without any desire to belittle the work of other investigators, we must say that these would have been inexplicable if the systems of transliteration followed by Grotefend and Saint Martin had been employed, and whatever else may be theirs, Rawlinson's, discovery at this period of the phonetic values $k h, b, m$ and $n$ is beyond all doubt. About this time he decided that the translation of the Persian cuneiform texts could only be effected by a knowledge of Zend, and he set to work to master the contents of the work of Anquetil du Perron and M. Burnouf's commentary on the Yacna, which was, however, not in his hands until 1838 ; he obtained some assistance, too, from a priest of Yezd, who translated for him some Zend MSS. In 1838 Rawlinson discovered the phonetic values of $h, w, i, v, t h$ and $j h$, and in 1839 he had practically settled the alphabet, which in all essential points agreed with that of Lassen, published in his Alt-persischen Keilinschriften. Here must be noted the fact that Rawlinson never contested the priority of alphabetical discovery with Lassen, even though there is abundant proof that all he owed to Lassen was a single phonetic value; but what he did claim, and claim rightly, was the credit of having translated literally and grammatically two hundred lines of cuneiform writing which contained historical statements of the greatest value, for the first time, as early as I 839. In this year, while he was putting the final touches to his work, political necessity caused him to be sent from Persia to Afghanistan, and his studies were so much interrupted during the next five years, that he was unable to publish the result of his labours until $1847 .{ }^{1}$

Meanwhile the mound of Kouyunjik, which marks the site of the palaces of ancient Nineveh, was being explored by Mr. Layard, and the mound of Khorsabad, some few miles off, had begun to yield splendid results to its talented excavator, M. Botta. That Kouyunjik formed part of old Nineveh was always well known, and so far back as $1820 \mathrm{Mr}$. Rich picked up three fragments of clay tablets inscribed in cuneiform writing. As soon as Rawlinson could obtain copies of the inscriptions dug out by Mr. Layard, he devoted himself to the study of them, and the practical outcome of these labours were his publications:- "A Commentary on the Cuneiform Inscriptions of Babylonia and Assyria; including readings of the inscription on the Nimrud Obelisk, and

1 In the tenth volume of the Jon rnal of the Royal Asiatic Society. (London, 1847.)

$$
\text { No. } 1327 \text {, VOI. 5 I] }
$$

